\title{
Peltojen ravinnetietokannasta apua maatalouden vesistökuormituksen vähentämiseen
}

Antti Miettinen $^{1)}$, Jussi Kauppila ${ }^{2)}$, Kauko Koikkalainen ${ }^{3)}$

1) Luonnonvarakeskus (Luke), Yliopistokatu6 B,80100Joensuu,antti.miettinen@luke.fi

2) Suomen ympäristökeskus (SYKE), Latokartanonkaari 11, 00790 Helsinki, jussi.kauppila@ymparisto.fi

3)Luonnonvarakeskus (Luke),Latokartanonkaari 9, 00790 Helsinki,kauko.koikkalainen@luke.fi

\section{TIIVISTELMÄ}

Vesiensuojelutavoitteiden saavuttaminen, vesiensuojelutoimien tehostaminen ja niiden tarvelähtöinen kohdentaminen edellyttää peltolohkojen ja niillä tehtävien viljelytoimenpiteiden tuntemusta, koska ympäristösuojelutoimenpiteiden vaikuttavuus vaihtelee peltolohkoittain. Kattavaa ja ajantasaista tietoa peltolohkojen ravinnetilasta ja niillä tehtävistä toimenpiteistä ei kuitenkaan ole viranomaisten tai tutkijoiden käytössä. Tarvittavat tiedot löytyvät viljelijöiden lohkomuistiinpanoista, mutta lohkokorttien sisältämiä tietoja ei ole koottu peltolohkorekisteriin perustuvaan paikkatietopohjaiseen tietokantaan.

Mikäli tiedot kaikista peltolohkoista, niiden ravinnetilasta ja peltolohkoilla tehtävistä viljelytoimenpiteistä saataisiin koottua yhteen valtakunnalliseen tietokantaan, voitaisiin paikkatietopohjaista ravinnetietokantaa käyttää viljelyn tukena, pelloilta vesistöihin tulevan ravinnekuormituksen arviointiin ja ympäristösuojelutoimenpiteiden kohdentamiseen. Vaativampia vesiensuojelutoimenpiteitä kohdennettaisiin niille peltolohkoille, joilta riski ravinteiden päätymisestä vesistöihin on suuri. Ravinnetietokanta mahdollistasi myös vesistöystävällisen viljelyn osoittamisen, lantalogistiikan kehittämisen sekä ympäristötoimenpiteiden suunnittelun valuma-alueittain alueen viljelijöiden kesken.

Ravinnetietokannan luomiseen, ylläpitoon, kehittämiseen ja hyödyntämiseen liittyy sekä käytännöllisiä että yhteiskunnalliseen ja oikeudelliseen hyväksyttävyyteen liittyviä haasteita. Tiedot ravinnetietokantaan tulee kerätä mahdollisimman kattavasti olemassa olevista tietolähteistä ja tietokannoista, tietokantojen rajapintoja tietojen siirrossa hyödyntäen. Tietokannan suunnittelun ja toteuttamisen oikeudellisena haasteena on erityisesti henkilötietojen suojan ja ympäristötiedon avoimuuden yhteensovittaminen.

Suomen Kulttuurirahaston rahoittamassa Samassa vedessä -hankkeessa tuotetaan tutkimustietoa maatalouden tietoperustan vahvistamiseksi, vesiensuojelutoimien tehostamiseksi ja ympäristöohjauksen kehittämiseksi. Hankkeen yhdessä osatutkimuksessa selvitetään haastattelujen ja työpajatyöskentelyn avulla paikkatietopohjaisen peltojen ravinnetietokannan perustamisedellytykset, muotoillaan luonnos tietokannan rakenteesta sekä ehdotus ravinnetietokannan käyttöä koskevasta sääntelystä. Lisäksi arvioidaan ravinnetietokannan perustamis- ja ylläpitokustannuksien suuruutta.

Asiasanat: fosfori, vesistökuormitus, ympäristösääntely 


\section{Johdanto}

Yli puolen Suomesta vesiin päätyvästä ihmistoimintojen aiheuttamasta ravinnehuuhtoumasta arvioidaan olevan peräisin maataloudesta. Maatalous on merkittävä vesistöjen hajakuormittaja erityisesti peltovaltaisilla valuma-alueilla.

Vesien- ja merenhoidon tavoitteena on suojella, parantaa ja ennallistaa pinta- ja pohjavesiä niin, että saavutetaan vesistöjen ja Itämeren hyvä tila. Vesiensuojelutavoitteiden saavuttaminen ja maatalouden vesiensuojelutoimien tehostaminen edellyttävät vesistöjen ja peltolohkojen ominaisuuksien sekä lohkoilla tehtävien viljelytoimenpiteiden tuntemusta. Tiedot peltolohkojen ravinnetilasta ja niillä tehtävistä toimenpiteistä eivät kuitenkaan tällä hetkellä välity kattavasti ja ajantasaisesti viranomaisten tai tutkijoiden käyttöön. Heikko tietopohja haittaa vesiensuojelutoimien tehostamismahdollisuuksia.

Kaikki maatalouden pinta-alaperusteisia tukia saaneet peruslohkot on digitoitu maataloushallinnon valtakunnalliseen peltolohkorekisteriin. Euroopan unionin (EU) kokonaan tai osittain rahoittamia viljelijätukia tai kansallisia viljelijätukia hakeneiden on noudatettava täydentäviä ehtoja, jotka muodostuvat hyvän maatalouden ja ympäristön vaatimuksista sekä lakisääteisistä hoitovaatimuksista (Ruokavirasto 2020). Kotieläintalouden toimintaa ja ympäristövaikutuksia ohjataan myös ympäristöluvituksella ja yleisellä ilmoitusmenettelyllä. Lisäksi valtaosa suomalaisista viljelijöistä on sitoutunut maatalouden ympäristökorvausjärjestelmään. Ympäristösitoumusten sitoumusala oli vuonna 2018 hieman yli 2,05 miljoonaa hehtaaria eli noin 90 \% käytössä olevasta maatalousmaasta (MMM 2018, Luke 2019). Ympäristösitoumuksen antaneet viljelijät on velvoitettu tekemään viljavuustutkimuksia ja lohkokohtaisia muistiinpanoja. Tiedot peltojen ravinnetilasta, lannoituksesta ja viljelytoimenpiteistä jäävät silti pääsääntöisesti viljelijöiden lohkomuistiinpanoihin ja hyödyttävät pelkästään viljelijöitä itseään, sillä tietoja ei tarvitse luovuttaa viranomaisille muuten kuin tukivalvontojen yhteydessä.

Maatalouden vesiensuojelussa tarvittava tieto on hajanaista, joten olemassa olevat tiedot peltolohkoista, niiden ravinnetilasta ja peltolohkoilla tehtävistä viljelytoimenpiteistä näkökulmasta tarkoituksenmukaista koota koko yhteiskuntaa hyödyttävään paikkatietopohjaiseen ravinnetietokantaan. Tietokannan avulla maatalouden ympäristönsuojelutoimet voitaisiin kohdentaa tarvelähtöisesti (Cosens ym. 2014). Vaativimpia toimenpiteitä toteutettaisiin niillä pelloilla, joilla riski ravinteiden päätymiselle vesistöihin on suurin (Marttinen ym. 2017). Oletuksena on, että ravinnetietokannan avulla voitaisiin parantaa sääntelyn vaikuttavuutta ja kustannustehokuutta (Kauppila ym. 2017).

Samassa vedessä -hankkeeseen kuuluvan tutkimuksen tavoitteena on tarkastella ravinnetietokannan perustamiseen ja käyttöön liittyviä haasteita sekä kartoittaa ravinnetietokannan toteuttamisvaihtoehtoja, jotta suunniteltuun ravinnetietokantaan saataisiin kerättyä mahdollisimman laajasti ja kustannustehokkaasti laadultaan korkeatasoista ja luotettavaa tietoa useisiin eri käyttötarkoituksiin sopivassa muodossa. Hanke on vielä käynnissä, joten tässä esitettävät tulokset ravinnetietokannan toteuttamisvaihtoehdoista ovat vasta alustavia.

Käytännöllisten haasteiden lisäksi ravinnetietokannan muodostamiseen, ylläpitoon ja käyttöön liittyy kysymyksiä ravinnetietokannan perustamisen ja käytön oikeudellisista rajoista ja edellytyksistä. Lainopillisen analyysin lisäksi tutkimukseen kuuluu myös viljelijöiden näkemyksiä kartoittava tarkastelu ravinnetietokannan hyväksyttävyyden edellytyksistä ja niistä ehdoista, joilla viljelijät ovat halukkaita luovuttamaan lohkokohtaisia tietoja ravinnetietokantaan. Näiden tarkastelujen tai lainopillisen analyysin tuloksia ei käsitellä tässä.

\section{Materiaalit ja menetelmät}

Ravinnetietokannan tarkoitusta, merkitystä, ja toteuttamisvaihtoehtoja selvitettiin laadullisella tutkimusotteella järjestämällä työpajoja ja haastattelemalla asiantuntijoita. Eri sidosryhmiä edustavien henkilöiden kokemuksen ja näkökulmien avulla pyrittiin saamaan kokonaisvaltainen käsitys tarpeista, joita ravinnetietokannan tulisi palvella. 
Vuoden 2019 aikana järjestettiin kolme työpajaa. Työpajoihin osallistui asiantuntijoita maa- ja metsätalousministeriöstä, Ruokavirastosta, ympäristöministeriöstä, ELY-keskuksista, Maa- ja metsätaloustuottajain Keskusliitosta, ProAgria Keskusten Liitosta, lannoiteteollisuudesta, Suomen Biokierto ja Biokaasu ry:stä, viljavuuslaboratorioista, viljelysuunnitteluohjelmistotaloista sekä Luonnonvarakeskuksesta ja Suomen ympäristökeskuksesta.

Ensimmäisen työpajan tavoitteena oli kartoittaa suunnitteilla olevan ravinnetietokannan lähtökohdat ja toimijoiden verkosto sekä määrittää ravinnetietokannan tavoitetila. Toisessa työpajassa haettiin ravinnetietokannan toimintamallia, keskusteltiin ravinnetietokannan sisällöstä ja roolista suhteessa muihin tietojärjestelmiin sekä tarvittavista kannustimista tietojen luovuttamiseksi ravinnetietokantaan. Lisäksi pohdittiin millaisten muutosten mahdollistaja ravinnetietokanta voisi olla. Kolmannessa työpajassa osallistujille esiteltiin kolme erilaista ravinnetietokannan toteuttamisvaihtoehtoa, ja työpajaan osallistuneet joutuivat punnitsemaan niiden käyttökelpoisuutta, tietokantaan kerättävien tietojen kattavuutta sekä tietokannan muodostamisesta viljelijöille aiheutuvaa taakkaa.

Työpajoissa saatuja tietoja syvennettiin ja täydennettiin asiantuntijahaastatteluilla. Vuosina 2018 ja 2019 haasteltiin kaikkiaan 16 asiantuntijaa. Haastatellut olivat samoista organisaatioista kuin työpajoihin osallistuneet, mutta kuitenkin pääsääntöisesti eri henkilöitä kuin työpajoihin osallistuneet. Haastatteluissa hyödynnettiin yhteistä haastattelurunkoa. Haastattelurungossa oli kysymyksiä muun muassa siitä, keitä kaikkia ja mitä tehtäviä Samassa vedessä -hankkeessa suunniteltavan digitaalisen peltolohkokohtaisen ravinnetietokannan tulisi ensisijaisesti palvella ja mitä tietoja ravinnetietokantaan tulisi sisällyttää.

\section{Tulokset ja tulosten tarkastelu}

\section{Lähtökohta}

Nykytila peltojen lohkokohtaisen ravinnetiedon ja viljelytoimenpiteiden osalta on johdannossa kuvatun mukainen: yhtä keskitettyä valtakunnallista tietokantaa ei ole olemassa.

Työpajatyöskentelyn ja asiantuntijahaastattelujen perusteella vahvistui käsitys, että peltolohkokohtaista ravinnetietoa on pääsääntöisesti saatavilla ainoastaan viljelijöiden lohkomuistiinpanoista. Tieto on yleensä kirjattu myös viljelysuunnitteluohjelmistoihin ja esimerkiksi ProAgrialla on kattava lohkotietopankki, jolloin tieto viljelijöiden omista lohkoista on viljelijöiden ja neuvojien käytössä. Ruokavirastossa on tiedot lannoitevalvonnassa olleilta lohkoilta. Valvontatiedot ovat suppeita kokonaisuuteen nähden, koska valvottavien tilojen lukumäärä on melko pieni (noin $5 \%$ vuosittain). Lisäksi jonkin verran paikkatietoon sidottua dataa muodostuu täsmäviljelylaitteita käytettäessä.

Peltolohkon viljavuustietoja on myös viljavuuslaboratoriolla, jotka tekevät viljavuustutkimuksia. Viljelijäasiakkaiden valtuutuksella tiedot voi saada viljavuuslaboratorioista, mutta kokemusten perustella tietoa joutuu työstämään tutkimustarkoituksiin. Tutkimushankkeet ovatkin hyödyntäneet lohkokohtaista ravinnetietoa, mutta tutkimusraporteista yksittäisiä lohkoja tai viljelijöitä ei voida yksilöidä, joten ne eivät sovellu lohkokohtaisen tiedon lähteiksi.

\section{Tavoite ja tavoitetila}

Vuonna 2019 järjestetyissä työpajoissa todettiin, että ravinnetietokanta ei ole lupahallinnon, maataloustukien valvonnan eikä tukien käsittelyn järjestelmä. Työpajoissa käytyjen keskustelujen perusteella ravinnetietokannan tavoitteeksi asetettiin koota peltolohkoihin liittyvät viljavuustiedot ja viljelytoimet kaikista Suomen viljellyistä peltolohkoista. Tällöin tavoitetilassa ravinnetietokannan avulla saadaan kattava kuva peltolohkojen ravinnetilasta ja niissä tapahtuneista muutoksista.

Tietokantaa voidaan käyttää viljelyn tukena sekä pelloilta vesistöihin tulevan ravinnekuormituksen arviointiin ja vähentämiseen ympäristönsuojelutoimenpiteitä tehostamalla ja kohdentamalla. Ravinnetietokanta antaa lähtötietoja tutkimukselle ja faktoja politiikkatoimien suunnitteluun. Se lisää kiertotalouden mahdollisuuksia ja ympäristötietojen avoimuutta huolehtien samalla yksityisten tietojen tietosuojasta. 


\section{Toimijoiden näkökulmia ja toiveita}

Ravinnetietokantaa suunniteltaessa ja käyttöönotettaessa on huomioitava ne toimijat, jotka voivat vaikuttaa ravinnetietokantaan ja myös ne toimijat, joiden toimintaan ravinnetietokanta voi vaikuttaa. Tärkeimpiä toimijoita ja samalla tiedon tuottajia ovat viljelijät. Muita keskeisiä toimijoita ovat maatalousneuvojat, viljelysuunnitteluohjelmistojen toimittajat, analyysipalveluiden tekijät (viljavuuslaboratoriot), maatalous- ja ympäristöhallinto sekä tutkijat. Taulukkoon 1 on kuvattu keskeisimpien toimijoiden ravinnetietokannalle asettamia odotuksia.

Taulukko 1. Keskeisimpien toimijoiden näkökulmia ja ravinnetietokannalle asettamia toiveita

\begin{tabular}{ll}
\hline Toimija & Näkökulma \\
\hline Viljelijä & Ravinnetietokanta ei saa lisätä hallinnollista taakkaa. Ravinnetietokannan \\
& tiedoista tulisi saada käytännön hyötyä viljelyyn. Ei saa tulla esim. kahteen \\
& kertaan tiedon tallentamista eri paikkoihin. Tietojen tulisi olla käytettävissä \\
& myös kolmansien osapuolten ohjelmistojen avulla. Muiden tietojen \\
& yhdistäminen ravinnetietokantaan tulisi olla mahdollista. Viljelijällä on voitava \\
& olla mahdollisuus vaikuttaa tietojensa käyttöön (MyData) vähintään muun kuin \\
& viranomais- ja tutkimuskäytön osalta. Pelkona on, että tietojen käyttö laajenee \\
& eri tarkoitukseen alkuperäisestä tarkoituksesta.
\end{tabular}

Neuvoja Ravinnetietokannan käyttöliittymä kannattaisi ehkä suunnitella neuvojien tarpeita silmällä pitäen. Neuvojan on voitava käyttää ja muokata ravinnetietokannan tietoja viljelijän puolesta (viljelijän valtuutuksella). Tiedot muualta (esim. viljavuusanalyysi) on saatava helposti ravinnetietokantaan. Tarve yhteentoimivuuteen viljelysuunnitteluohjelmistojen kanssa.

Viljelysuunnitteluohjelmiston toimittaja

Viljavuuslaboratorio

Ruokavirasto

Maa- ja

metsätalousministeriö

Ympäristöministeriö

Tutkija
Ravinnetietokannan tiedot tulee olla saatavissa viljelysuunnitteluohjelmistoon. Tietojen siirto viljelysuunnitteluohjelmiston ja ravinnetietokannan välillä rajapinnan kautta. Erilaisten integraatioiden määrä tulisi pitää pienenä. Luokitustietojen yhteensopivuus on tarkistettava. Tällä hetkellä viljelysuunnitteluohjelmistoissa on erilaiset kasvikoodit kuin maataloushallinnon ohjelmistoissa. Lannoitetietojen osalta tarvitaan ajantasainen lannoiterekisteri.

Viljavuusanalyysin tiedot ovat välitettävissä ravinnetietokantaan helposti rajapinnan avulla.

Perustietojen välittäminen ravinnetietokannan kanssa on voitava hoitaa rajapintojen avulla samaan tapaan kuin viljelysuunnitteluohjelmistojen kanssa. Voidaan tutkia yhteisten rajapintojen käyttöä (esim. karttarajapinta). Lohkokohtaiset tiedot (maalaji, kylvöaika, lannoitus) helpottaisivat lohkolla viljeltävien kasvien tunnistusta ja parantaisivat monitorointia, jos/kun kaikki lohkot valvotaan tulevaisuudessa. Viljelijää voitaisiin myös informoida satopotentiaalin arvioimisessa.

Ilman tietokantaakin on pärjätty. Jos tietokanta olisi olemassa, se avaisi mahdollisuuksia, ja siitä olisi varmaankin hyötyä pitkällä aikavälillä. Pitäisi arvioida tarvitaanko koko maan kattavaa totaaliaineistoa vai voitaisiinko tyytyä otoksiin. Tämä on myös kustannuskysymys.

Yksityiskohtaisempaa fosforitietoa tarvittaisiin erityisesti toimenpiteiden kohdentamiseen. Biomassa-atlas ja ravinnetyökalu auttavat, mutta vesienhoidon suunnittelussa tarvittaisiin vieläkin yksityiskohtaisempaa fosforitietoa toimenpiteiden kohdentamisen taustaksi.

Tiedon keräämisjärjestelmän tulee mahdollistaa kaikkien lohkotietojen kerääminen, vaikka niitä kaikkia ei heti kerättäisikään. Ravinnetietokantaan tulisi sisällyttää seuraavat lohkokohtaiset tiedot: Lannoitteen laatu, ravinnemäärät ja lannoituksen ajankohta. Kylvöaika, sadon määrä ja sadonkorjuun ajankohta. Maalaji, P-luku ja multavuustieto. Hiilen kiertoa mallinnettaessa tärkeitä tietoja ovat myös muokkausmenetelmä, sadonkorjuun ja muokkauksen ajankohta sekä peltoon jäävän oljen määrä. 


\section{Ravinnetietokannan tietosisältö}

Ravinnetietokannan mahdollinen tietosisältö hahmoteltiin ensimmäisissä työpajoissa yleisellä tasolla ottamatta vielä kantaa erilaisiin toteutusvaihtoehtoihin. Oleellisena pidettiin, että kerätyt tiedot ovat liitettävissä paikkatietoon (perus- ja kasvulohkorekisteriin sekä uoma- ja valuma-aluetietoon).

Tärkeitä viljavuustietoja ovat maalaji, multavuus, johtoluku, kationinvaihtokapasiteetti, $\mathrm{pH}, \mathrm{Ca}, \mathrm{K}, \mathrm{P}$, $\mathrm{Mg}$ ja S. Ne tulisivat olemaan myös keskeinen osa ravinnetietokannan lohkokohtaisia tietoja. Viljavuustutkimuksessa määritettyjä tietoja tarvitaan viljelyn suunnittelussa ja niillä on vaikutusta myös ympäristön tilaan. Esimerkiksi viljavuustutkimuksen perustutkimuksessa määritetty maan helppoliukoisen fosforin pitoisuus vaikuttaa varsin suoraviivaisesti liukoisen fosforin vesistökuormitukseen.

Työpajakeskusteluissa ja asiantuntijahaastatteluissa tuli ilmi, että ravinnetietokantaan tallennettaviksi suunniteltuihin viljavuustutkimuksen tuloksiin liittyy luotettavuusongelmia. Näytteenoton ohjeistus voi olla puutteellista. Lisäksi näytteenottoon sisältyy myös mahdollisuus toimia vilpillisesti, koska viljelijät ottavat viljavuustutkimuksen maanäytteet itse, eikä näytteenottoa valvota. Jotta viljavuustiedot olisivat käyttökelpoisia, maanäytteet on otettava oikeasta syvyydestä ja lohkon kokonaisuuden kannalta edustavasta paikasta. Mikäli viljelijät toimivat jatkossakin näytteenottajina, heille tulisi luoda kannustin toimia oikein. Nykyään viljelijöillä saattaa olla joissain tapauksissa kannustin manipuloida näytteenottoa saadakseen haluamansa tuloksen, koska ympäristökorvaukseen sitoutuneella tilalla fosforilannoituksen kasvilajikohtaisiin enimmäismääriin vaikuttaa peltolohkon viljavuusluokka, joka määräytyy maalajin, multavuuden ja maan fosforipitoisuuden mukaan.

Osa työpajoihin osallistuneista ja haastatelluista oli sitä mieltä, että pelkästään ravinnetietoihin ei kannata rajoittua, vaan tietokantaan voisi siirtää myös lohkokorttiin liittyviä tietoja, kuten viljelytoimet, viljellyt kasvilajit, muokkausmenetelmät ja kasvinsuojeluaineiden käyttö. Viljelijät ovat myös tuoneet esille, että tarvittaisiin tiedot/todisteet suomalaisten peltojen vähäisestä raskasmetallipitoisuudesta, kun ruokaa myydään ulkomaille, jotta ruoan puhtaus voidaan osoittaa.

Viljelysuunnitelma ja -toteuma ovat myös kiinnostavia tietoja. Näistä toteuma on ravinnetietokannan kannalta tärkeämpi, sillä satotiedot mahdollistavat ravinnetaselaskennan yhdessä lannoitustietojen kanssa. Viljelijälle on merkittävää hyötyä myös suunnitteluun liittyvistä tiedoista, joten myös ne voitaisiin sisällyttää ravinnetietokantaan. Suunnittelutiedot mahdollistavat myös viljelyneuvonnan.

Ravinnetietokantaan voitaisiin sisällyttää myös suunnitelmat ja tiedot lannanlevityksestä. Tämä edesauttaisi lannanlevityksen suunnittelua ja antaisi kokonaiskuvan lannan käytöstä ja lannan sisältämistä ravinteista. Ravinnetietokannalla voisi tulevaisuudessa olla liittymä normilantajärjestelmään (Luostarinen ym. 2017).

\section{Muutostekijöiden huomioiminen tietosisällön suunnittelussa}

Ravinnetietokannan tietosisällön suunnittelussa tulee myös ennakoida muutostrendejä, jotta uusia tietoja voidaan tarvittaessa myöhemmin sisällyttää ravinnetietokantaan. Esimerkiksi peltomaan hiilen määrän seuranta tulee todennäköisesti mukaan ympäristökorvausjärjestelmään EU:n ohjelmakaudelle 2020-2027, jolloin tieto maaperään varastoituneen hiilen määrästä voitaisiin sisällyttää ravinnetietokantaan.

Tietoja pitäisi myös pystyä viemään ravinnetietokannasta viljelyneuvonnan sähköisiin palveluihin sekä mahdollisiin muihin välineisiin, kuten suunnitteilla olevaan ravinnetyökaluun. Euroopan komission ehdotus on, että ravinnesuunnittelu koskisi kaikkia maatiloja, mutta EU:n jäsenmaat ovat ehdottaneet, että FaST (Farm Sustainability Tool for Nutrients) olisi osa neuvontajärjestelmää, jolloin ravinnesuunnitelman tekeminen olisi viljelijälle vapaaehtoista.

\section{Ravinnetietokannan hyödyt}

Ravinnetietokannan suunnittelussa on pyrittävä siihen, että siitä on hyötyä keskeisille toimijoille. Taulukossa 2 on lueteltu työpajoissa tunnistettuja ravinnetietokannan potentiaalisia hyötyjä. 
Taulukko 2. Ravinnetietokannan mahdollisia hyötyjä

$\begin{array}{ll}\text { Benchmarking } & \text { Ravinnetietokannan avulla viljelijät ja neuvojat voivat vertailla lohkojen } \\ \text { tietoja toisiin vastaavanlaisiin peltolohkoihin ja suunnitella toimenpiteitä sen } \\ \text { mukaan ja arvioida mahdollisia kustannussäästöjä. }\end{array}$

Tuotantopanosten optimointi

Ravinnetietokannan avulla voidaan tarkastella ravinnetasetta verrattuna suunniteltuun viljelyyn, jolloin lannoitusta ja perusparannustoimia voidaan optimoida tarpeen mukaan.

Sadon lähtötietojen

jäljitettävyys

Lantalogistiikan kehittäminen

Ympäristötoimenpiteiden suunnittelu yhdessä

Ympäristöystävällisyyden osoittaminen
Ravinnetietokannan avulla voidaan osoittaa millä menetelmillä ja lannoitteilla sato on tuotettu sekä osoittaa esim. raskasmetallien pitoisuudet viljelyolosuhteissa.

Ravinnetietokannan avulla voitaisiin laatia yksinkertaisemmat säännöt lannanlevityksen suunnitteluun ja yksinkertaistaa (tai jopa poistaa) lupakäsittelyä. Lisäksi ravinnetietokannan avulla voidaan löytää kohtuullisen matkan päässä sijaitsevia peltoja, jotka voivat ottaa vastaan lantaa.

Vesistöjen ja valuma-alueiden kuormituksia voidaan arvioida paremmin ravinnetietokannan avulla ja tämän perusteella voitaisiin sopia ympäristötoimenpiteiden suunnittelusta alueen viljelijöiden kesken.

Tietokannan avulla on mahdollista osoittaa, että viljely on toteutettu vesistöystävällisesti.

Koko yhteiskunnan tasolla arvioitaessa ratkaisevaa on, että ravinnetietokannasta koituu enemmän hyötyjä kuin mitä tietokannan perustamisesta ja ylläpidosta aiheutuu kustannuksia.

\section{Keskustelua toteutusvaihtoehdoista}

Ravinnetietokannan toteutusvaihtoehtoja pohdittiin lokakuussa 2019 järjestetyssä kolmannessa työpajassa. Hankkeen tutkijat olivat valmistelleet arvioitaviksi kolme vaihtoehtoa. Mikään vaihtoehdoista ei noussut keskusteluissa selvästi muita paremmaksi, vaan kaksi laajuudeltaan erilaista toteutusvaihtoehtoa (minimi ja optimi) arvioitiin yhtä hyviksi. Kolmas vaihtoehto (medium) ei saanut kannatusta. Kahden eniten kannatusta saaneen toteutusvaihtoehdon ominaisuuksia on esitelty Taulukossa 3.

Kummatkaan eniten kannatusta saaneista toteutusvaihtoehdoista eivät lisäisi kohtuuttomasti viljelijöiden kokemaa hallinnollista taakkaa. Etenkin minimivaihtoehdossa hallinnollinen taakka ei käytännössä lisääntyisi lainkaan, sillä lähes $90 \%$ suomalaisista viljelijöistä kuuluu maatalouden ympäristökorvausjärjestelmään, jolloin he joutuvat tekemään viljavuustutkimuksen viiden vuoden välein.

Optimivaihtoehdossa edellytetään myös lohkokorteilla olevien tietojen siirtämistä tai tallentamista ravinnetietokantaan. Tavoitteena on, että tiedot siirtyisivät ravinnetietokantaan viljelysuunnitteluohjelmistojen rajapintojen kautta. Ongelmana on teknisten kysymysten lisäksi myös se, että osa viljelijöistä ei käytä viljelysuunnitteluohjelmistoja, jolloin he joutuisivat tallentamaan tiedot ravinnetietokantaan esim. www-palvelun kautta. Lohkokohtaisten ravinnetaseiden laskemista varten optimivaihtoehdossa ravinnetietokantaan tulisi tallentaa myös lohkokohtainen sato, jonka luotettava arvioiminen on vaikeaa.

Toteutusvaihtoehtojen arvioinnissa ei otettu kantaa siihen, velvoitettaisiinko viljelijät luovuttamaan tiedot ravinnetietokantaan vastikkeettomasti tai olisiko tietojen luovuttaminen tietokantaan esimerkiksi ympäristökorvauksen saamisen ehtona. Tietojen luovuttaminen ravinnetietokantaan voi myös olla vapaaehtoista, mutta tällöin viljelijät tarvitsevat kannustimia tietojen luovutukseen, jotta järjestelmästä saadaan riittävän kattava. Periaatteessa lohkokohtaisille tiedoille voisi myös syntyä markkinat ja tiedot voisivat olla kauppatavaraa. 
Taulukko 3. Ravinnetietokannan mahdollisia toteutusvaihtoehtoja

\begin{tabular}{|c|c|c|}
\hline & Toteutusvaihtoehto "Minimi" & Toteutusvaihtoehto "Optimi" \\
\hline $\begin{array}{l}\text { Tietokantaan } \\
\text { kerättävät tiedot }\end{array}$ & $\begin{array}{l}\text { Ravinnetietokantaan kootaan tärkeimmät } \\
\text { viljavuusanalyysien tiedot. }\end{array}$ & $\begin{array}{l}\text { Ravinnetietokantaan kootaan tärkeimpien } \\
\text { viljavuusanalyysin tietojen lisäksi myös } \\
\text { lohkokorttien tiedot, jolloin tietokantaan } \\
\text { saadaan ravinnetietojen lisäksi myös tiedot } \\
\text { peltolohkoilla tehdyistä toimenpiteistä sekä } \\
\text { satotiedot. }\end{array}$ \\
\hline \multirow[t]{2}{*}{$\begin{array}{l}\text { Tietokannan } \\
\text { tekninen } \\
\text { toteutustapa }\end{array}$} & $\begin{array}{l}\text { Viljavuusanalyysien tiedot ovat teknisesti } \\
\text { helposti saatavissa viljavuusanalyysejä } \\
\text { tekeviltä palveluntuottajilta rajapinnan } \\
\text { kautta. }\end{array}$ & \multirow{2}{*}{$\begin{array}{l}\text { Viljavuusanalyysien tiedot ja peltolohkojen } \\
\text { sijaintitiedot siirretään samalla tavalla kuin } \\
\text { minimivaihtoehdossa. } \\
\text { Lohkokorttien tiedot siirretään ensisijaisesti } \\
\text { viljelysuunnitteluohjelmistoista rajapinnan } \\
\text { kautta. Niille viljelijöille joilla ei ole } \\
\text { käytössä viljelysuunnitteluohjelmistoa, pitää } \\
\text { rakentaa esim. www-palvelu, jonka avulla } \\
\text { ilmoitetaan ja ylläpidetään lohkokorttien } \\
\text { tietoja. }\end{array}$} \\
\hline & $\begin{array}{l}\text { kautta. } \\
\text { Aineistossa on oltava peruslohkon tunnus, } \\
\text { minkä jälkeen siihen voidaan yhdistää } \\
\text { sijaintitiedot Ruokaviraston peltolohko- } \\
\text { rekisteristä. }\end{array}$ & \\
\hline Päivitystiheys & Viljavuusanalyysien tulokset joka 5. vuosi & $\begin{array}{l}\text { Viljavuusanalyysien tulokset joka } 5 \text {. vuosi } \\
\text { Muut tiedot vuosittain }\end{array}$ \\
\hline $\begin{array}{l}\text { Tietokannan } \\
\text { muodostamisen } \\
\text { taakka }\end{array}$ & $\begin{array}{l}\text { Toteutusvaihtoehto ei käytännössä lisää } \\
\text { hallinnollista taakkaa ympäristökorvaukseen } \\
\text { sitoutuneille viljelijöille. Ympäristö- } \\
\text { korvauksen ulkopuolella oleville viljelijöille } \\
\text { (noin } 10 \% \text { kaikista viljelijöistä) taakka } \\
\text { lisääntyy jonkin verran. }\end{array}$ & $\begin{array}{l}\text { Käytännössä hallinnollinen taakka ei } \\
\text { juurikaan lisäänny niillä viljelijöillä, jotka } \\
\text { käyttävät viljelysuunnitteluohjelmistoja ja } \\
\text { ovat sitoutuneet ympäristökorvaus- } \\
\text { järjestelmään. Niiden viljelijöiden taakka } \\
\text { lisääntyy, jotka eivät käytä viljely- } \\
\text { suunnitteluohjelmistoja tai ole sitoutuneita } \\
\text { ympäristökorvausjärjestelmään. }\end{array}$ \\
\hline
\end{tabular}

\section{Johtopäätökset}

Tutkijaryhmä tulee todennäköisesti esittämään, että ravinnetietokanta tultaisiin ensivaiheessa toteuttamaan minimivaihtoehdon mukaisesti, jolloin ravinnetietokannasta saataisiin tutkimuksessa sekä ohjauskeinojen ja politiikkatoimenpiteiden suunnittelussa tarvittavat välttämättömät peltolohkojen ravinnetiedot. Minimivaihtoehdon mukaisesti toteutettava ravinnetietokanta ei lisäisi kohtuuttomasti viljelijöiden kokemaa hallinnollista taakkaa.

Viljelijät voidaan velvoittaa luovuttamaan tiedot ravinnetietokantaan tai tietojen luovuttaminen voi olla vapaaehtoista. Lohkokohtaiset ravinnetiedot voivat myös olla kauppatavaraa. Osa viljelijöistä suhtautuu kielteisesti pakollisuuteen, joten vapaaehtoisuuteen perustuva järjestelmä olisi siinä mielessä tarkoituksenmukaisempi. Pelkästään vapaaehtoisuuteen perustuvassa järjestelmässä tietokantaan ei ehkä saada kerättyä tietoja riittävän kattavasti.

Ravinnetietokannan perustamisesta ja ylläpitämisestä aiheutuvat kustannukset arvioidaan Samassa vedessä -hankkeessa vuoden 2020 aikana päätöksenteon tueksi. Samalla selvitetään ehdotettavaan toteutusvaihtoehtoon sopiva rahoitusmalli ja tutkitaan, voitaisiinko ravinnetietokannan ylläpitoa rahoittaa muullakin tavoin kuin valtion budjettirahoituksella.

Myöhemmin ravinnetietokannan tietosisältöä voitaisiin laajentaa kokeiluhankkeista saatavien tulosten perusteella. Ennen ravinnetietokannan tietosisällön mahdollista laajentamista eri toimijoiden käyttämät erilaiset kasvikoodit tulisi yhdenmukaistaa. Lisäksi tarvitaan lannoitevalmisterekisteri ja TUKESin kasvinsuojeluainerekisteriin pitäisi luoda rajapinta, jonka kautta rekisteristä voitaisiin hakea tietoa. 


\section{Kiitokset}

Tutkimus on yksi Suomen Kulttuurirahaston rahoittaman Samassa vedessä -hankkeen osatutkimuksista. Tutkijat kiittävät kaikkia työpajoihin ja haastatteluihin osallistuneita asiantuntijoita sekä Conversatum Oy:n Jaakko Wegeliusta, Jaroslaw Skwarekia, Jatta Tommista ja Maria Laurilaa hyvästä yhteistyöstä ja työpajajärjestelyistä.

\section{Kirjallisuus}

Cosens, B.A., Gunderson, L. \& Chaffin, B. 2014. The Adaptive Water Governance Project: Assessing Law, Resilience and Governance in Regional Socio-Ecological Water Systems Facing a Changing Climate. Idaho Law Review 51: 1-27.

Kauppila, J., Ekholm, P., Niskanen, O., Valve, H. \& Iho, A. 2017. Muuttuva kotieläintalous ja vesistökuormituksen sääntely. Teoksessa: Määttä, T., Kumpula, A., Kokko, K., Sairinen, R. \& Similä, J. (toim.). Ympäristöpolitiikan ja -oikeuden vuosikirja X. Joensuu: Itä-Suomen yliopiston LYY-instituutti: Luonnonvarat, ympäristö, yhteiskunta. Itä-Suomen yliopisto, Oikeustieteiden laitos. s. 227-273.

Luke 2019. Käytössä oleva maatalousmaa 2018. Viitattu 23.1.2020. Päivitetty 11.4.2019. https://stat.luke.fi $/ \mathrm{k} \% \mathrm{C} 3 \% \mathrm{~A} 4 \mathrm{yt} \% \mathrm{C} 3 \% \mathrm{~B} 6 \mathrm{ss} \% \mathrm{C} 3 \% \mathrm{~A} 4$-oleva-maatalousmaa-2018_fi-0

Luostarinen, S., Grönroos, J., Hellstedt, M., Nousiainen, J. \& Munther, J. 2017. SUOMEN NORMILANTA laskentajärjestelmän kuvaus ja ensimmäiset tulokset. Luonnonvara- ja biotalouden tutkimus 47. Helsinki: Luonnonvarakeskus. $54 \mathrm{~s}$.

Marttinen, S., Venelampi, O., Iho, A., Koikkalainen, K., Lehtonen, E., Luostarinen, S., Rasa, K., Sarvi, M., Tampio, E., Turtola, E., Ylivainio, K., Grönroos, J., Kauppila, J., Koskiaho, J., Valve, H., Laine-Ylijoki, J., Lantto, R., Oasmaa, A. \& zu Castell-Rüdenhausen, M. 2017. Kohti ravinteiden kierrätyksen läpimurtoa: Nykytila ja suositukset ohjauskeinojen kehittämiseksi Suomessa. Luonnonvara- ja biotalouden tutkimus 45. Helsinki: Luonnonvarakeskus. $45 \mathrm{~s}$.

MMM. 2018. Vuotuinen täytäntöönpanokertomus. Manner-Suomen maaseudun kehittämisohjelma 2014-2020. Viitattu 23.1.2020. Päivitetty 28.5.2019.

https://www.maaseutu.fi/globalassets/vuosikertomukset/maaseutuverkoston-vuosiraportit/manner-suomenmaaseudun-kehittamisohjelman-2014-2020-vuoden-2018-raportti.pdf

Ruokavirasto 2020. Täydentävät ehdot 2020. Viitattu 23.1.2020. https://ruokavirasto.mobiezine.fi/zine/615/pdf 